\title{
Is Lack of Morality an Explanation for the Economic and Financial Crisis? A Catholic Point of View
}

\author{
Klára Katona ${ }^{1}$ (D)
}

Published online: 20 November 2020

(C) The Author(s) 2020

\begin{abstract}
Before 2008, several studies provided empirical evidence of a positive correlation between the functions of financial intermediation and economic growth. In 2008, the financial crisis shook trust in this correlation. Several studies found that comprehensive and fundamental changes were needed in the entire financial market. Attention focused on the role of morality as an essential and integral element of the economy, arguing that without a moral attitude at the individual and institutional levels, the whole system necessarily runs into crisis. Among the moral interpretations of the economy, which are concurrently based on philosophical tradition and religious doctrine, the Catholic Church has presented some of the most consistent and unified teachings related to such questions over time, but the effect on economic thinking is less than what relevance and other merits justify. Catholic social teaching suggests morality and the economy are inseparable and highlights the moral interpretation of economic discrepancies. By analyzing theoretical and empirical evidence, this paper assesses the economic validity and legitimacy of Catholic thought about the immanent role of ethics in the economy and the financial crisis.
\end{abstract}

Keywords Financial crisis $\cdot$ Catholic thoughts $\cdot$ Ethics $\cdot$ Morality $\cdot$ Financial system $\cdot$ CST

JEL $\mathrm{G} 10 \cdot \mathrm{G} 20$

Klára Katona

katona.klara@jak.ppkehu

1 Pázmány Péter Catholic University in Hungary, Szentkirályi utca 28-30,

Budapest H-1088, Hungary 


\section{Introduction}

Before the 2008 financial crisis, relevant background literature supported a strong connection between the functions of financial intermediation and economic growth. The fundamental function of the financial-intermediary sector, which collects savings and allocates them to finance investments, highlights a direct connection between financial intermediation and economic growth. Several empirical studies examined this theoretically perceivable relationship (e.g. Cetorelli and Gambera, 2001; Guiso et al., 2004). Another relevant function of the financial market is monitoring and evaluation. It is too expensive for other stakeholders to control the management of the firms. However, banks could successfully undertake this control (Diamond 1984). Long-term cooperation between banks and corporations may also decrease costs derived from informational asymmetry. A developed financial system not only accelerates economic production but also reduces the volatility of investment and growth by providing liquidity to firms (Larrain 2006).

In 2008, the financial crisis undermined absolute faith in a theoretically and empirically assessed correlation between financial intermediation and economic prosperity. As a negative spillover effect, the United States (U.S.) financial system crisis quickly expanded to the entire world economy. The financial system could not contribute to economic growth. Instead, it enhanced the economic recession. The system increased risks in the economy and the volatility of investments, and could not monitor firms effectively either. How could this happen when the starting point of the crisis was the U.S., a country that has one of the most developed and liberalized financial systems in the world?

Before 2008, several distinguished economists identified discrepancies between economic models and real economic reactions, foreseeing the possibility of a crisis. They suggested complex reform of both the entire financial system and market economy (e.g. Arrow 1992; Stiglitz 2002). Among proposals for fundamental change in the economic system, lack of morality was identified as a possible explanation for the economic crisis in general and especially for the 2008 financial crisis. However, moral interpretation of the economy and the concept of morality itself can vary based on differing philosophical traditions and religions (Taylor 2014, pp. 34-38). Morality can be measured by indices, such as the Freedom from Corruption or World Index of Moral Freedom, which regard religiosity as a negative factor in relation to other moral criteria (Crabtree 2020). At the same time, there is a venerable tradition of reconciling economics with the moral concept of major faiths from Ibn Khaldún (1332-1406) in Islam to Weber's (1930) famous work on Protestant ethics. The religious approach received further confirmation in contemporary literature and validated the economic relevance of morality from different religious views, such as Buddhism, Hinduism, Islam, Judaism and Christianity (e.g. Zsolnai 2010; Vinod 2013; Addas 2008; Sedláček 2011).

Alternatively, the link between morality and economics is neither evident nor widely accepted in the economics literature, such as the Chicago or Austrian schools of economics which deny the economic relevance of ethics (Mises 1951, pp. 45-50; Friedman 1970, p. 17). Those economists who described economic actions without moral considerations also provided reasons for the 2008 financial crisis and offered solutions to prevent crises independent of ethical aspects. 
Contrary to the morally neutral interpretation of the economy in mainstream literature, this study supports an opposing economic viewpoint and tries to theoretically and empirically explain the ethical concerns of economics from the special perspective of the Catholic Church. Among major religions, for more than 100 years the Catholic Church has had one of the most consistent and unified teaching concerning this question. The Catholic Church has drawn attention to the inseparability of morals and the workings of the economy in several papal encyclicals which built successively on each other, confirming and making more sophisticated the statements of each previous one. Catholic social teaching (CST) emphasizes the importance of morality in every human activity, including economic activity. CST declares that there is no domain of economics with its own facts and laws. The economic sphere is part of human activity. Precisely because it is human, it must be structured and governed in an ethical manner (Benedict XVI 2009, §7, 53). The Catholic Church also suggests that without ethics, the economy will function incorrectly.

This study is novel in its ability to reveal that CST is not only part of the moral philosophy but also suggests valid explanations and solutions for dysfunctions in and reasons for the financial crisis. The paper highlights those principles of CST which argue for the role of morality in economics, and tries to demonstrate the economic validity and legitimacy of Catholic thought by analyzing theoretical and empirical evidence of economic discourse on the driving force of the economy and possible reasons for the crisis.

\section{Role of Homo Oeconomicus and the Invisible Hand in CST}

The reference and starting point in most of the economic debates is Smith's (1776) book and his two conceptions about homo economicus and the invisible hand. According to neoclassical interpretations of the term homo economicus, this market actor is an economic agent who is rational, self-interested and pursues subjectively-defined preferences optimally based on knowledge of what is best for long-term physical and mental health. This agent always acts in a way that maximizes utility as a consumer and profit as a producer and is capable of arbitrarily complex deductions towards that end. Pursuing his or her own selfinterest, homo oeconomicus can also serve the public good through the function of the invisible hand. The metaphor of the invisible hand describes the unintended social benefits of individuals' self-interested actions because the self-regulating coordinating system of the market can result in equilibrium. Several relevant economists considered this metaphor the most important macroeconomic category in economics (e.g. Hayek 1991a, p. 148; Tobin 1991). Referring to this concept, neoclassical economics argues for pursuing self-interest in all economic actions of market actors regardless of any moral consideration, because it is the most effective way to serve the public good. Friedman (1970), the emblematic representative of the Chicago school, also shared these thoughts in his famous article. Mises (1951, pp. 45-50), the leading economist of the Austrian school, also argued for the exclusive role of the consumer as the final arbiter of what is produced and distributed without including any ethical point of view. He argued for value-free economics and was an opponent of considering any objective ethics in economics.

CST rejects the homo oeconomicus approach to man because this self-interested utility maximizer is not a truly ontological construct of the person. Decisions on 
economic matters are made by the same humans who make decisions on moral, aesthetic or, simply, family matters. The person should be understood in a more complete way (John Paul II 1991§24). Homo oeconomicus and homo sociologicus represent the same person whose morality is not limited to practicing virtues, such as prudence and rationality. When the Catholic Church rejects the concept of homo oeconomicus, it does not construct an idealistic human personality. On the contrary, it is based on thousands of years' experience in real human behavior and weaknesses. The Catholic Church points out the dangerous consequences of the kind of limitation and simplification of human beings which the idea of the homo oeconomicus suggests. At the same time, CST expects a high-moral level for participants of (economic) life, which essentially exceeds the requirements of the market, including rationality and prudent decisions.

The concept of homo oeconomicus is controversial in both psychological and economic literature. In psychological terms, homo oeconomicus is a self-interested, individualistic person, who pursues material wealth to the exclusion of all other motivations and can be identified as a sociopath (Hinze 2011, p. 160). Research based on laboratory experiments questioned the validity of the homo oeconomicus model. Gintis's (2000) results, in accordance with other similar studies, showed that economic actors are not self-regarding, but rather, in many circumstances, are strong reciprocators who bring to strategic interactions a propensity to cooperate. Behavioral economics also draws attention to the limitations of the homo oeconomicus approach and those macroeconomic models based on rational expectations. Such models neglect the real feature of human behavior which depends on context and is affected by several psychological effects. Thaler and Sunstein (2017) identified behavioral psychological factors that discourage market players' decisions from the assumptions of the models based on rational expectations and influence the validity of these models. They identified three behavioral economic reasons for the subprime credit crisis: limited rationality, which prevented investors from estimating the real risks of mortgage constructions and derivatives, lack of self-control, which sometimes can have destructive consequences, and power of social influence, which convinced market actors that the real-estate boom would never end. The authors commented that greed, corruption or merely incapacity of purpose contributed to the development of the latest crisis (Thaler and Sunstein 2017, p. 308-312). They concluded that the human being is not homo oeconomicus but Homo sapiens. The 2008 financial crisis was not independent of either the model of homo oeconomics or a view of business exclusively through an economic lens. Tangible reasons for the financial crisis were rooted in pursuing selfinterest, which neglects any moral aspects (Argandona et al., 2011, p. 1-4).

The Catholic Church also refuses the concept of the invisible hand as an automatic mechanism that results in an unintended social benefit of individuals' self-interested actions. As Pope Benedict XVI said, the illusion that the economy was somehow "autonomous... has led man to abuse the economic process in a thoroughly destructive way" (Benedict XVI 2009, §34). Ethics requires efforts from all participants of the economy. Social benefit is not an automatic result of economic activities. Pope Benedict XVI also stressed that as a consequence of unquestioning belief in market autonomy, the financial sector diverged from its original function, and speculation became dominant, which does not serve the interests of society. Pope Pius XI highlighted the harmful effect of the principle of a self-regulated free market saying, 
"This concentration of power and might, the characteristic mark, as it were, of contemporary economic life, is the fruit that the unlimited freedom of struggle among competitors has of its own nature produced, and which lets only the strongest survive" (Pius XI 1931,§107).

Pope Francis also pointed out the unsustainability of neoclassical market conception,

"which assume(s) that economic growth, encouraged by a free market, will inevitably succeed in bringing about greater justice and inclusiveness in the world. This opinion, which has never been confirmed by the facts, expresses a crude and naive trust in the goodness of those wielding economic powers and in the sacralized workings of the prevailing economic system" (Pope Francis $2013, \S 54)$.

It is important to stress the fact that the only use of the invisible hand found in Smith (1776) is in Book IV, Chapter II. The concept was first introduced by Smith (1759), invoking it in reference to income distribution. The idea of the market is not discussed and the word capitalism is never used in this work (Madarász 2014, p. 827; Fazekas 2016, p. 1128). Without Smith (1759), the interpretation of the invisible hand is incomplete. Smith, who was also a professor of moral philosophy, emphasized utility's connection with beauty and virtue (Horkay Hörcher 1996, pp. 295-395). He also argued that the goal of the market is cooperation: the division of labor which serves mutual advantages. In this context, the whole free-market economy is based on trust, cooperation and moral actions. They are the foundations of successful market functioning.

Denying the importance of morality in a neoliberal interpretation of the market economy was given specific attention and criticism in recent economic literature prior to the 2008 crisis. Arrow (1992) already emphasized that the "relaxation of moral standards and an over-vivid exaltation of the markets and of the value of greed in the last decade have led to new abuses" (Arrow 1992, pp. 19-21). He argued that the market should not be the final arbiter. "Actions of individuals must be governed by moral considerations of consequences and by legal controls" (Arrow 1992, pp. 19-21). In Stiglitz (2002), systemic corruption in global markets and institutions is detailed. He argued that the collusion of large numbers of people in financial and economic circles, buttressed by the free-market ideology of neoliberalism, manipulated the levers of the global economy in their own financial interest. "Decisions were made on the basis of what seemed a curious blend of ideology and bad economics, dogma that sometimes seemed to be thinly veiling special interests," (Stiglitz 2002, p. 245). For much of the world, globalization as it has been managed, has brought greater volatility and insecurity and more inequality. It has even threatened fundamental values (Stiglitz 2010, p. 292). "We have created an economy and a society in which great wealth is amassed through rent seeking, sometimes through direct transfers from the public to the wealthy, but mostly through monopoly power and other forms of exploitation," (Stiglitz 2012, p. 266). The solution is a moral renovation of economics, according to Stiglitz. The distressing world income inequality trend is not only a theoretical question, it is a real problem supported by empirical evidence. According to the 2018 World Inequality Report, while the share of the global top $1 \%$ in global income rose, the share of the 
global bottom 50\% was stagnant between 1980 and 2015 (Alvaredo et al. 2018, p. 9). High inequality not only harms ethics or social justice, but also reduces economic growth. The rise in inequality observed between 1985 and 2005 in 19 Organisation for Economic Cooperation and Development (OECD) countries knocked 4.7 percentage points off cumulative growth between 1990 and 2010 (OECD 2015, p. 26). American economy productivity increased by $85 \%$ between 1977 and 2014, but the profit went to the highest classes and others practically did not receive any compensation from it (Reich 2016, pp. 67-86).

As an implication of the 2008 financial crisis, the validity of the invisible-hand concept and market automatism in equilibrium were also compromised. Stiglitz declared that "To me, the major lessons of the global financial crisis were that this model [invisible hand] was discredited, and there is an urgent need to create models and policies based on more realistic analyses of the economy" (Stiglitz 2010, p. 2).

The financial system in its present form increases, rather than reduces, risks which suggests that the spontaneous order and self-correction of the financial market does not work. Arcand et al. (2015, p. 117) pointed out that after a tipping point, increasing financial intermediation contributes to increasing financial instability. Thus, uncontrolled financial-sector growth cannot play its part in the economy and does not serve the common good, one of the main principles of CST. Theoretical and empirical evidence confirm the necessity of considering moral aspects in the economy and in the financial crisis paying special attention to reinterpreting the concepts of homo oeconomicus and the invisible hand as CST has emphasized for more than a hundred years.

\section{Financial Crisis Therapies Using CST Principles}

CST states that without ethics, the economy does not function correctly. To highlight those features of ethics in Catholic teachings that can provide solutions to revisit the role and target of financial intermediation, the economic validity of four main principles in CST need to be examined: subsidiarity, solidarity, the common good and the dignity of the human being. Subsidiarity means that nothing should be assigned to a larger community that can be accomplished by a lesser and subordinate entity (Pius XI 1931, $\S 79)$. Pope Pius XI pointed out that subsidiarity is used as a norm for task sharing among governmental and private actors within civil society. In this sense, subsidiarity works in two ways. It defends subordinate entities from the illegitimate overregulation of higher political instances, and it constitutes a right of assistance if solving their problems is out of reach for the subordinate entities. Pope Benedict XVI strengthened the importance of subsidiarity in managing globalization. Under the conditions of the global economy, subsidiarity can also be considered as an organizational principle for shaping responsibilities and interrelations among political, civil and economic actors in a globalizing society (Benedict XVI 2009, §57).

In accordance with this principle, additional economic studies concluded that the main reason for the 2008 crisis was the overexpansion of the government (Yandle 2010; O'Brien 2017). The U.S. government distorted market operations through political pressures and subsidies to make home ownership affordable, even for individuals who could not afford to own houses, and forced mortgage banks to lend 
subprime credits. ${ }^{1}$ Wallison (2016) also contended that the crisis was caused by government housing policies. At the same time, the government shifted the responsibility for the financial risks of these credits to banks. When the volume of bankruptcies became dangerous, the U.S. government granted bailouts to banks at the expense of American taxpayers. To shift risks of subprime credits, banks issued mortgage-backed securities that were sold to investors all over the world. Due to the real-estate collateral, these securities were overvalued in risk-return relationships by rating agencies misrepresenting the investors. As a consequence, the sale of these securities essentially increased. Mortgage banks used a shadow banking system ${ }^{2}$ in the sale of mortgagebacked securities to get rid of rigorous regulations on capital. As a result of securitization and the operation of a shadow banking system, the distance between the original debtor and the investor, who actually holds the risks of crediting, increased and became non-transparent. Credit default swap (CDS) construction ${ }^{3}$ was originally developed to decrease mortgage credit risk, but building in different new products. Non-transparent, toxic constructions were developed and contributed to expanding the financial crisis worldwide. CDS was not a voluntary construction, but was prescribed by law (Kessler 2009).

Several authors argued that a proper, rigorous, but not over expanded regulation could be a final solution for the financial crisis. Gorton and Metrick (2010) found that more rigorous regulation, e.g. regulation of the shadow banking system, can moderate the uncertainties of the financial sector. This recommendation is searching for a solution within the system, reflecting on the neoclassical theory of the market economy and considering proper regulation as the answer to the problems of markets. "Problems 'of the market' should be seen rather as the pitfalls of the legal system" (Hayek 1973, p. 88). Rajan (2011) also declared that it is possible to design a prudent and wellstructured financial-intermediary sector by controlling the ratio of large banks, limiting the possibility for insider dealing, which does not increase financial uncertainties and has a positive impact on economic growth. Sanders (2014) supported a new regulatory system based on the principle of subsidiarity that delegates certain control to professional bodies.

Prudent legal regulation of financial intermediation that reflects subsidiarity is in accordance with Catholic teachings. At the same time, CST also stresses doubts about the effectiveness of renovating regulatory systems without an ethical attitude. From the Catholic point of view, rights are not absolute. Law is not a priori. It is a product of its particular time and involves certain styles of thinking. Justice does not require endorsement for the existing distribution of wealth and bargaining capability. Reforming law is not the proper way to foster individual dignity and promote social welfare. The fact is that after all crises, new institutions and legal regulations were introduced to eliminate the causes of the collapse or recession, but crises happened repeatedly. It shows that

\footnotetext{
${ }^{1}$ Subprime credits are loans or credits made to a borrower with a low-credit rating, high-debt levels and no property or assets that can be used as collateral

${ }^{2}$ The shadow banking system is the group of financial intermediaries facilitating the creation of credit across the global financial system but whose members are not subject to regulatory oversight. The shadow banking system also refers to unregulated activities by regulated institutions.

${ }^{3} \mathrm{CDS}$ is a particular type of swap designed to transfer the credit exposure of fixed-income products between two or more parties. CDS is the most common form of credit derivative and may involve municipal bonds, emerging market bonds, mortgage-backed securities or corporate bonds.
} 
regulation is necessary but not sufficient to reduce or eliminate the risk of crises (Zingales 2015). Without an ethical attitude, legal regulation per se is not a proper means to enforce economic requirements or social justice (Millon 1993, p. 1373).

In 2008 beyond the ineffectiveness of the regulatory system, the lack of social responsibility and unethical attitudes at the personal and system levels in the financial sector also contributed to the development of the latest financial crisis (McCormick 2011). Using industry data from Inside Mortgage Finance, Fligstein and Roehrkasse (2016) quantitatively analyzed and estimated a model of mortgage-backed securities fraud suits and predatory lending suits settled in 2009-2014. Their results supported the argument of CST, questioning the conventional wisdom of the neoclassical and institutional economic theories about the relationship between market structure, regulation and economic behavior. The volume and distribution of fraud throughout the markets for mortgage origination highlighted the limitations of this wisdom. Deregulation or technical opacity identified only necessary, but not sufficient conditions. According to this research, the structure of firms and markets caused fraud. Increased scarcity and competition within markets catalyzed widespread illegal behavior. Firms' positions within and across markets shaped its extent and character. Zingales (2015, p. 1344) also considered fraud in the financial sector as a feature, a usual part of business, the amount of which is enormous.

Yandle (2010) pointed out that in the subprime-crediting process, all actors made moral mistakes, shaking faith and trust in the institutions, which, evidently, led to the collapse of financial and market processes and resulted in an economic crisis. Hayek (1991b, pp. 32-44) considered trust as the main driving force of market economy. According to Hayek, trust plays a vital role in small-group settings, where informal rules and traditions form a basis for trust. In the absence of market-generated, trustforming devices, transacting parties cannot afford enough police and regulators to induce honest behavior among ordinary people. Trust and trust-assuring mechanisms can be low-cost substitutes for police, regulators and court actions. Several studies examined the role of trust in the economic performance of countries. Recently, Kasmaoui et al. (2018, p. 6) found a positive association between generalized trust and economic growth using data from the 2010-2014 wave of the World Value Survey and employing econometric specifications. The results suggest that countries with a high level of trust also display a higher level of income per capita.

The dominant business culture in the financial sector also undermined the ethical norms of employees (Cohn et al., 2014). The vis bonus system rewards short-term profit maximization and undertaking higher risks, providing enormous income transfer to the representatives of the financial sector. Due to this policy and behavior that neglects risk and pursues profit, financial innovations became increasingly complicated and not transparent. Empirical evidence showed that the more complicated financial constructions were sold to less competent investors (Célérier and Vallee, 2017, p. 1491). This reflects a total lack of solidarity, another main principle of CST. Solidarity means that all members of society have a responsibility to help other members of their community with the needs that they cannot remedy themselves.

The message of CST is that the purpose of business activity is not simply to make a profit. It must also serve the needs and welfare of the people involved in the business and that of the particular society where the firm works. Profits undermine the otherwise desirable creation of wealth if they do not recognize the common good as the ultimate 
goal and principle of CST as well (Benedict XVI 2009, §21). If profit is the result of the exploitation of workers or misrepresentation of buyers, as happened when nontransparent financial innovations were sold to investors who were not professional, it avoids the obligations of social justice and violates the rights of business partners. Therefore, a business enterprise should rather be taken as a community of solidarity which must maintain the welfare of its people, its owners and the environment, i.e. a social ecology (John Paul II 1991). CST supports the investment approach in managerial decisions, which means long-term financial perspectives (Benedict XVI 2009, $\S 40)$. Without a moral attitude, managerial decisions are not acceptable. Ethics should be integrated into the structure of managerial action. Respect of the common good and responsible managerial behavior are not only noble vocations of business but can contribute to a better financial performance of a firm and finally to a sustainable financial and economic system. Using environmental, social and governance (ESG) ratings data from the Morgan Stanley Capital International (MSCI) ESG STATS database (formerly KLD) Cornetta et al. (2016, p. 158) found that banks, especially larger banks that were most heavily criticized for their obsession with profits and for their lack of social conscience prior to the financial crisis, did work to improve their corporate social responsibility (CSR) after the crisis by lowering deposit fees and increasing services to low-income communities. The results showed that CSR engagement is associated with higher bank performance. Another benefit of increased CSR is that the likelihood of another crisis is lower.

\section{Conclusions}

The 2008 financial crisis shook the trust in the correlation between the financial system and economic growth fundamentally. The financial system became dysfunctional and destroyed the economic growth perspectives. By not monitoring the firms effectively, it increased risks in the economy and extended the volatility of investments. The starting point of the crisis was the U.S., a country which has one of the most developed and liberalized financial systems in the world. Attention was drawn to explanations from the neoliberal interpretation of the market economy. Moral problems were identified as behind these negative developments. The Catholic Church argued for the immanent role of ethics in all human activities, including economic activities, in its social teachings for more than a hundred years. This study aimed to examine the ethical concerns of the economy and the latest financial collapse from the perspective of the Catholic Church. CST can suggest appropriate and valid explanations and solutions for the economic inconsistencies and reasons for the latest financial crisis.

CST neglects the homo oeconomicus approach of men because personality cannot be narrowed to practicing rationality or pursuing self-interest. The 2008 financial crisis was not independent of economic theories based on the homo oeconomicus model of the human being, as psychological research and behavioral economics literature also highlighted. CST refuses automatism of the invisible hand as a mechanism that results in an unintended social benefit of individuals' self-interested actions. The distressing trend of world income inequality, the growing financial instability before 2008 and the crisis itself also questioned the existence of this automatism. The four main principles in CST can provide both explanations and solutions for the dysfunctions of financial 
intermediation and the economy. Negligence of the subsidiarity in U.S. government actions and the unethical attitudes which disregarded solidarity and common good both at the personal and system levels in the financial sector also contributed to the development of the latest financial crisis. Theoretical and empirical evidence of economic studies suggests that the principles of CST offer a solution to the problems that caused the latest economic crisis and are important driving forces of economic activities.

The Catholic Church does not create an alternative economic model, yet its social teaching can contribute to the discussions regarding the financial crises. The Church can invite economic actors to consider ethics, which defines human beings and all human activities in their complexity and takes into account actual circumstances.

Funding Open access funding provided by Pázmány Péter Catholic University.

Open Access This article is licensed under a Creative Commons Attribution 4.0 International License, which permits use, sharing, adaptation, distribution and reproduction in any medium or format, as long as you give appropriate credit to the original author(s) and the source, provide a link to the Creative Commons licence, and indicate if changes were made. The images or other third party material in this article are included in the article's Creative Commons licence, unless indicated otherwise in a credit line to the material. If material is not included in the article's Creative Commons licence and your intended use is not permitted by statutory regulation or exceeds the permitted use, you will need to obtain permission directly from the copyright holder. To view a copy of this licence, visit http://creativecommons.org/licenses/by/4.0/.

\section{References}

Addas, W, A, J. (2008). Methodology of Economics: Secular Versus Islamic. International Islamic University Malaysia press, 15 January 2008. 148. Last Accessed September 22, 2020. https://mpra.ub.uni-muenchen. de/8264/1/Methodology_of_Economics.pdf

Alvaredo, F., Saez, E., Chancel, L., Piketty, T., \& Zucman, G. (2018). World inequality report 2018. Cambridge, MA: The Belknap Press of Harvard University Press.

Arcand, J. L., Berkes, E., \& Panizza, U. (2015). Too much finance? Journal of Economic Growth, 20(2), 105148.

Argandona, A., Melé, D., \& Sanches-Runde, C. (2011). Facing the crisis. Toward a new humanistic synthesis for business, Journal of Business Ethics, 201199(1), 1-4.

Arrow, K. (1992). Moral Thinking and Economic Interaction in Social and Ethical Aspects of Economics. A Colloquium in the Vatican. Vatican City: Pontificial Council for Justice and Peace, 2nd edition 2011.

Benedict XVI (2009). Encyclical-Letter Caritas in Veritate, on Integral Human Development in Charity and Truth, 29th of June 2009, Libreria Editrice Vaticana Rome, www.vatican.va

Célérier, C., \& Vallee, B. (2017). Catering to investors through security design: Headline rate and complexity. Quarterly Journal of Economics, February 2017, 132(3), 1469-1508.

Cetorelli, N. and Gambera, M.(2001). Banking market structure, financial dependence and growth: International evidence from industry data, The Journal of Finance. Vol. 56, no. 2 April 2001, pp. 617648. https://www.jstor.org/stable/222576

Cohn, A., Fehr, E., \& Marécha, M. A. (2014). Business culture and dishonesty in the banking industry. Nature., 516 86-99.

Cornetta, M. M., Erhemjamtsa, O., \& Tehranianb, H. (2016). Greed or good deeds: An examination of the relation between corporate social responsibility and the financial performance of U.S. commercial banks around the financial crisis. Journal of Banking and Finance, 70, 137-159.

Crabtree, V (2020). What is the Best Country in the World? An Index of Morality, Conscience and Good Life, The Human Truth Foundation. http://www.vexen.co.uk/countries/best.html, Downloaded: 22.09.2020.

Diamond, D. W. (1984). Financial intermediation and delegated monitoring. Review of Economic Studies, $51(3), 393-414$ 
Fazekas, K. (2016). Tisztesség, empátia, közgazdaságtan (honesty, empathy economics). Közgazdasági Szemle, LXIII, 1120-1141.

Fligstein, N., \& Roehrkasse, A. (2016). The Causes of Fraud in Financial Crises: Evidence from the mortgagebacked securities industry. American Sociological Review, 81(4), 617-643.

Francis. (2013). Evangelii Gaudium, encyclical on the joy of the gospel. Rome: Libreria Editrice Vaticana www.vaticana.va.

Friedman, M. (1970). The social responsibility of business is to increase its profit, The New York Times Magazine, 17. https://www.nytimes.com/1970/09/13/archives/a-friedman-doctrine-the-socialresponsibility-of-business-is-to.html

Gintis, H. (2000). Beyond Homo economicus: Evidence from experimental economics. Ecological Economics, 35(3), 311-322.

Gorton, G. B., \& Metrick, A. (2010). Regulating the Shadow Banking System. Brookings Papers on Economic Activity, 41(2) Fall, 2010, 261-312.

Guiso, L., Sapienza, P., \& Zingales, L. (2004). Does Local Financial Development Matter? Quarterly Journal of Economics, 119(3), 929-969.

Hayek, F, A. (1973). Law, Legislation and Liberty - Rules and Orders, University of Chicago Press, Vol 1, Chicago, 1973, 88-89

Hayek, F, A. (1991a). The fatal conceit. The errors of Socialism. Chicago, Edited by W. W. Bartley, University of Chicago Press, Chicago, 1991, 192.

Hayek, F. A. (1991b). The trend of economic thinking: Essays on political economists and economic history. London: Routledge.

Hinze, C. F. (2011). Economic recession, work and solidarity. Theological Studies, 72(1), 150-169.

Horkay Hörcher, F. (1996). A mérséklet filozófiája a skót felvilágosodásban (Philosophy of modesty in Scottish Enlightenment). In F. Horkay Hörcher (Ed.), A skót felvilágosodás (Scottish enlightenment) (pp. 295-395). Budapest: Osiris.

John Paul II. (1991). Centesimus Annus, encyclical on the hundredth anniversary of Rerum Novarum, 1st of may 1991. Rome: Libreria Editrice Vaticana www.vatican.va.

Kasmaoui, K., Mughal, M., \& Bouoiyour, J. (2018). Does Trust Influence Economic Growth? Evidence from the Arab World. Economic Bulletin, 38(2), 1-13.

Kessler, A. (2009) Have we seen the last of the bear raids? Wall Street Journal. March 26, 2009, https://www. wsj.com/articles/SB123802165000541773

Larrain, B. (2006). Do Banks Affect the Level and Composition of Industrial Volatility? The Journal of Finance, 61(4), 1897-1925.

Madarász, A. (2014). A láthatatlan kéz - szemelvények egy metafora történetéből. (invisible hand -extracts from the history of a metaphor). Közgazdasági Szemle, LXI, 801-844.

McCormick, R. (2011). Towards a more sustainable finance system - part2. Creating an effective civil society response to the Crisis. Law and Financial Markets Review, 5, Issue(2), 129-138.

Millon, D. (1993). New directions in corporate law. Communitarians, Contractarians, and the crisis in corporate law. Washington and Lee Law Review, 50(4), 1373-1377.

Mises, L. (1951). Profit and loss. Whitefish, USA: Kessinger Publishing.

O'Brien, J. (2017). A question of trust. Post-truth paradigms and challenge to financial regulation, Law and Financial Markets Review, 11(1), 20-30.

OECD. (2015). In It Together: Why Less Inequality Benefits All. Paris: OECD publishing. https://doi. org/10.1787/9789264235120-en downloaded 22.09.2020.

Pius, XI. (1931). Quadragesimo anno, encyclical on reconstruction of the social order, 15th of may 1931. Rome: Libreria Editrice Vaticana www.vatican.va.

Rajan, R. M. (2011). Fault lines. How Hidden Fractures Still Threaten the World Economy. New Jersey, USA: Princeton University press revised ed. edition, august 28, 2011, 280.

Reich, R. (2016). Saving capitalism, For the Many, Not the Few. New York: Vintage Reprint edition, May 3, 2016.

Sanders D. (2014). Reinventing regulation, Law and Financial Markets Review, June 2014. 8(2), 98-102.

Sedláček, T. (2011). Economics of Good and Evil: The Quest for Economic Meaning from Gilgamesh to Wall 482 Street (p. 376). Oxford: Oxford University press.

Smith, A. (1759). The Theory of Moral Sentiments (p. 422). Indianapolis 1982: liberty fund Inc..

Smith, A. (1776). The wealth of nations (Vol. 1991, p. 590). Norwalk USA: Easton Press.

Stiglitz, J. E. (2002). Globalization and its discontents. London: Allen Lane/Penguin Books.

Stiglitz, J. (2010). The Stiglitz Report. Reforming the International Monetary and Financial Systems in the Wake of the Global Financial Crisis. New York: the new press. 
Stiglitz, J. E. (2012). Price of Inequality, How Today's Divided Society Endangers our Future. New York: W.W. Norton.

Taylor, T. (2014). Economics and. Morality, Finance and Development, 51(2), 34-38.

Thaler, R, H. \& Sunstein, C, R.(2017). Nudge: Improving decisions about health, Wealth, and Happiness, Penguin Putnam Inc. USA. 312

Tobin, J. (1991). The invisible hand in modern macroeconomics. Cowles Foundation Discussion Paper, (966), Cowles Foundation for Research in Economics, Yale University, New Haven, Connecticut, 1-16.

Vinod, H. D. (2013). Handbook of Hindu economics and business. Scotts Valley, USA: CreateSpace Independent Publishing Platform.

Wallison, P, J. (2016). Hidden in Plain Sight: What Really Caused the World's Worst Financial Crisis and Why It Could Happen Again, Encounter Books, 440.

Weber, M. (1930). The protestant ethic and the spirit of capitalism. London: Allen and Unwin (Orig. pub. 1904).

Yandle, B. (2010). Lost trust the real cause of the financial meltdown. The Independent Review, 14(3), 341361.

Zingales, L. (2015). Presidential address: Does finance benefit society? The Journal of Finance, 70(4), 13271862.

Zsolnai, L. (Ed.). (2010). Boldogság és gazdaság - A buddhista közgazdaságtan eszméi. (Happiness and Economy- the Ideas of the Buddhist Economics). Budapest: Typotex.

Publisher's Note Springer Nature remains neutral with regard to jurisdictional claims in published maps and institutional affiliations. 